\title{
GIS in the jungle: Experiential Environmental Education (EEE) in Panama
}

\author{
Dan Klooster $^{1}\left[\right.$ - Nathan Strout ${ }^{1} \cdot$ David Smith $^{1} \cdot$ Fundación Geoversity
}

Accepted: 13 July 2021 / Published online: 25 July 2021

(c) AESS 2021

\begin{abstract}
A University of Redlands travel course to Panama builds on Monty Hempel's legacy in environmental studies, Experiential Environmental Education, and geographic information systems (GIS) instruction at the University of Redlands. It follows his experience developing social relationships in Panama, and nearly 20 years leading an EEE travel course to Palau. This Panama course, nicknamed "GIS in the Jungle," tasks students with activities such as trail mapping, gathering original data with unmanned aerial vehicles (UAV), landcover mapping of pastures and forests, and visualizing the distribution of above-ground forest carbon content. These GIS activities help students construct an understanding of rainforest conservation that integrates their experiences living, hiking, and collecting original data in that environment. UAV and GIS also provided a platform for interacting with indigenous peoples struggling to defend their rainforest territory from colonist deforestation. As Monty Hempel observed about this course, students use GIS and UAV to integrate their direct experience with ground-level fieldwork in the rainforest with a birds-eye view of the interlocking ecosystems and human impacts. Combined with direct rainforest experiences, GIS projects help students develop an understanding of nature's interlocking systems and the interdependence of life on Earth.
\end{abstract}

Keywords Experiential Environmental Education · Geographic information systems · Field courses · Study abroad · Panama

\section{Introduction}

Experiential Environmental Education (EEE) immerses students in threatened environmental systems, enriching their experience with learning activities and applied projects that ideally contribute to environmental solutions. It inspires them to see and be inspired by the interconnectedness of

This article is modified from Klooster, D, Smith, D, Strout, N, Experience Mamoni, Fundación Geoversity (2019a) PanaMapping: GIS for conservation science. in: Wright D and Harder C (eds) GIS for science: Applying mapping and spatial analytics, Vol 1. Esri Press, Redlands, CA, Pp 200-213. The companion website includes collections of ArcGIS® StoryMaps stories, apps, and digital maps, bringing the real-world examples to life: www.GISforScience.com

Dan Klooster

Daniel_Klooster@Redlands.edu

University of Redlands, Redlands, CA, USA environmental systems, to care about human connections to those environmental systems, to learn environmental knowledge, and to understand their role in conservation (Brenner et al. 2013; Atalan-Helicke 2014; Jose et al. 2017; Felege et al. 2019; Moseley et al. 2020). Geographic information system (GIS) provides additional tools for students to build environmental knowledge and understanding. As opposed to learning about GIS, in which course activities are structured around the acquisition of GIS skills, course activities which use GIS activities to engage students in analytical environmental engagements, i.e., "learning with GIS" (Jakab et al. 2017), can be particularly useful in Experiential Environmental Education (Lo et al. 2002; Sinton 2009; Hwang 2013).

Starting in 2017, undergraduate students, faculty, and GIS professionals from the University of Redlands have been conducting month-long field courses in the Panamanian rainforest where they experience pristine, degraded, and 
Fig. 1 Monty Hempel produced a short film documenting the 2012 transcontinental expedition with Geoversity (Hempel 2012). Photo by Doug Bruce

recovering rainforest environments, learn about the social systems interacting with the forests, and complete GIS projects that bring together their developing understanding of rainforest dynamics and the social challenges of rainforest conservation.

The Panama course, nicknamed "GIS in the Jungle," reflects Monty Hempel's legacy promoting Experiential Environmental Education (EEE). PanaMapping is an "Environmental Design Studio," a type of course which Monty and his colleagues established at the University of Redlands to allow students to practice their GIS skills to analyze environmental problems and to develop solutions to environmental challenges outside the classroom. It is also a travel class inspired by Monty's long-term Palau Expedition $\mathrm{EEE}^{1}$ travel course, which also meets during the University of Redland's month-long May block term.

Monty was also the original contact between Panamanian collaborators and the University of Redlands. His first "visit" to the Mamoní Valley Preserve, where the course is based, took place in October 2009. Dr. Jane Goodall was visiting the preserve at the time, and via an audio link from the reserve's field lodge, she addressed the First Annual Conference of the Association for Environmental Studies and Sciences (AESS) in Madison, WI, where Monty was serving as the organization's first president. Her plenary session was accompanied by the pepper grinder sound from a pair of keel-billed toucans and the barking from a tribe of howler monkeys marauding in the fruit trees on a hillside near the preserve's jungle lodge (Nathan Gray cited in Klooster et al. 2019b). Later, Monty traveled to Panama to participate in a transcontinental hiking and river rafting expedition delivering a

\footnotetext{
${ }^{1}$ Monty and Marilyn Hempel first led the Palau Expedition in 2000. It continues now under the leadership of Professor Lei Lani Stelle, Professor of Biology, University of Redlands.
}

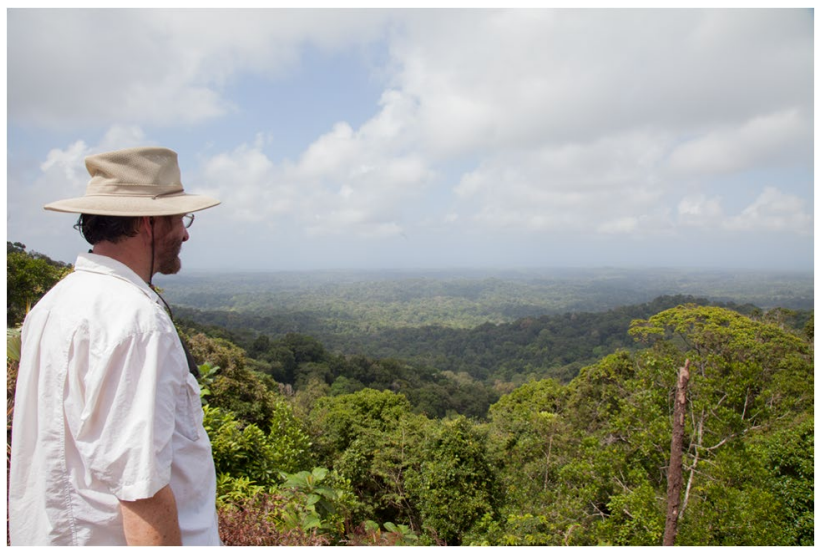

Fig. 2 Monty Hempel observes tropical forest protected by the Guna people. Photo by Doug Bruce

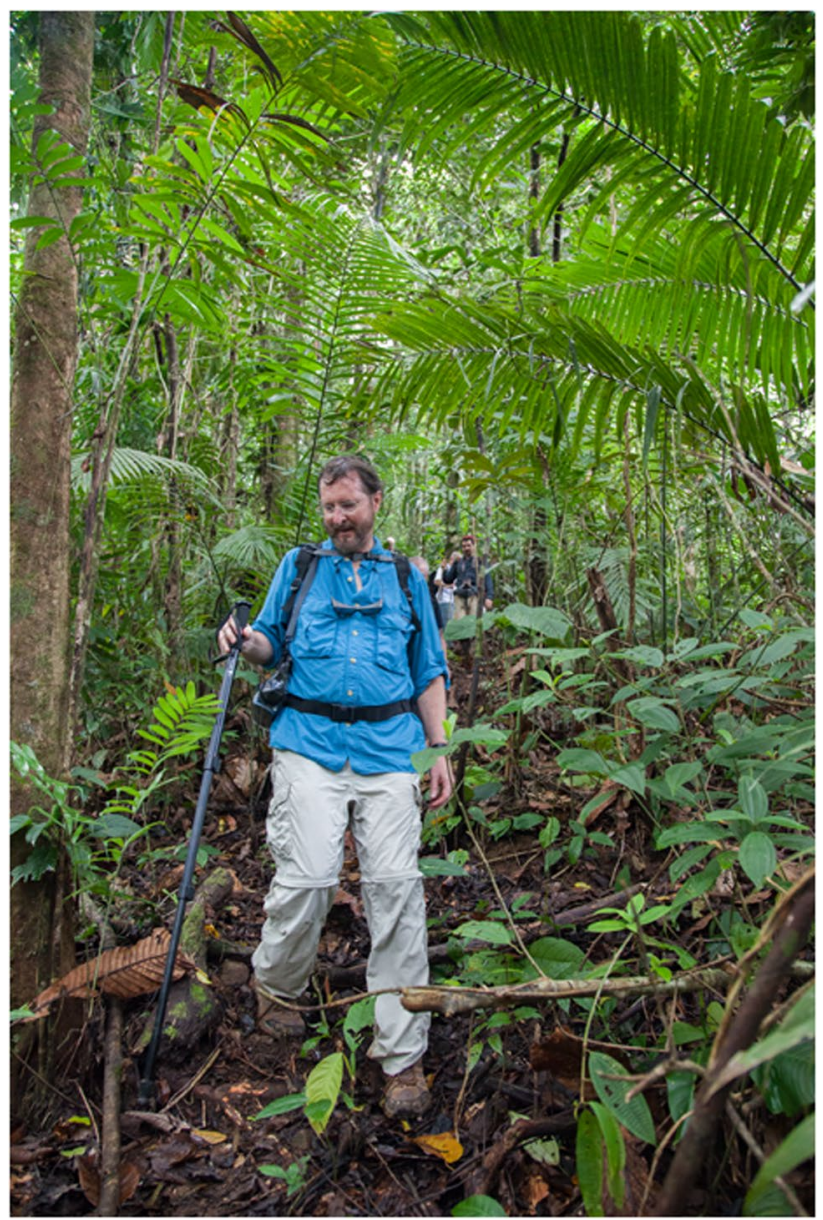

Fig. 3 Monty Hempel on a transcontinental expedition in Panama. University of Redlands students continue to experience tropical forests on similar hikes. Photo by Doug Bruce

kind of inspirational EEE to a group of environmentalists, business leaders, musicians, and film makers. This expedition led from the Mamoní Valley Preserve on the 
Fig. 4 Monty Hempel in a Panamanian tropical forest which continues to provide Experiential Environmental Education opportunities to University of Redlands faculty and students. Photo by Doug Bruce
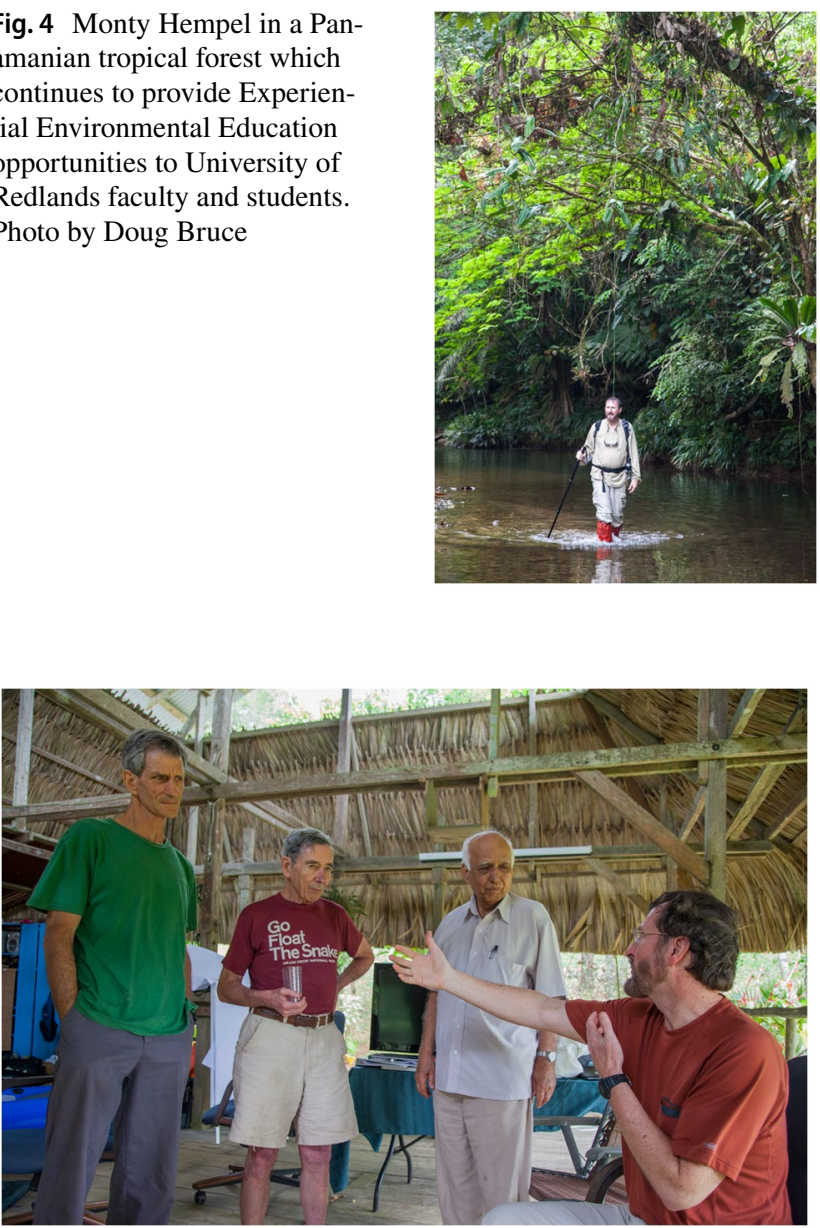

Fig. 5 Nathan Gray, John de Cuevas, Bapu Deolalikar, and Monty Hempel at the Mamoní Valley Preserve, 2012. University of Redlands students and staff continue to conduct Experiential Environmental Education in this open air gathering space at Geoversity's Centro Mamoní. Photo by Doug Bruce

Pacific side of Panama's continental divide through the autonomous territory of the Guna people and to the Atlantic coast (Hempel 2012; Figs. 1, 2, 3, 4, 5).

Monty declined an invitation to develop and teach a field class in this environment; he was already fully committed to a yearly EEE course in Palau. Instead, he invited Dan Klooster, a geographer with substantial experience researching and teaching in Latin America to take on this challenge. Together with University of Redlands staff in the Center for Spatial Studies, they built on the perspectives and relationships Monty established in order to build a course in which GIS becomes the lingua franca of student participation and a vehicle for the integration of environmental experiences with broad educational value.
The course has met in May of 2017, 2018, and 2019, and is planned to resume after a COVID-induced pause ${ }^{2}$ in May of 2022. Although the course best meets the needs of advanced environmental studies majors, undeclared first year students and non-EVST majors have also successfully completed the course. The only prerequisite is an introductory course in GIS. It fulfills several general education, environmental studies, and spatial studies requirements. The course typically starts with several days of orientation and GIS review on campus, followed by a flight to Panama, two and a half weeks at the Centro Mamoni rainforest research station, followed by then enrichment trips to an indigenous area and several days in Panama City. The course culminates with students making presentations of their GIS work to stakeholders in the Mamoní Valley Preserve.

\section{The Mamoní Valley Preserve, Panama}

The PanaMapping EEE course takes place in the upper Mamoní river valley, a rainforest frontier at the narrowest part of the Americas, where a line drawn through the preserve from the Pacific to the Atlantic would be only $60 \mathrm{~km}$ (37 miles) long. The valley helps to buffer the Chagres National Park and the pristine Guna Yala Comarca. It thickens the Mesoamerican Biological Corridor, and it strengthens the Tumbes-Chocó-Magdalena ecological hotspot. The valley, therefore, is a conservation priority. With the presence of indigenous peoples, colonists, cattle ranchers, and conservationists, it is also broadly representative of peopleforest dynamics elsewhere in the humid tropics. The upper Mamoní Valley watershed covers approximately $120 \mathrm{~km}^{2}$ (29,900 acres), about half of which is in properties affiliated with the Mamoní Valley Preserve (Fig. 6).

Students develop an understanding of this context as they experience ecosystems that shelter the full complement of tropical forest mammals, including jaguars, ocelots, pumas, jaguarundi, two species of sloths, five kinds of monkeys, and abundant snakes, lizards, and amphibians. Scientists from Harvard University and elsewhere have observed 290 species of birds here. The valley provides refuge for species of frogs decimated by disease elsewhere in Panama, and the Smithsonian Tropical Research Institute's Panama Amphibian Rescue and Conservation Project studies remnant frog populations and experiments with reintroductions.

\footnotetext{
2 The COVID-19 pandemic led to a cancelation of the planned 2020 version and rescheduling of the 2021 version as an on-campus semester-long course. Students did GIS projects related to the reserve using remote computers they could operate from their laptops and tablets. See a resulting ESRI story maps at https://arcg.is/1CnHbT.
} 


\section{Mamoní Valley Preserve, Panamá}

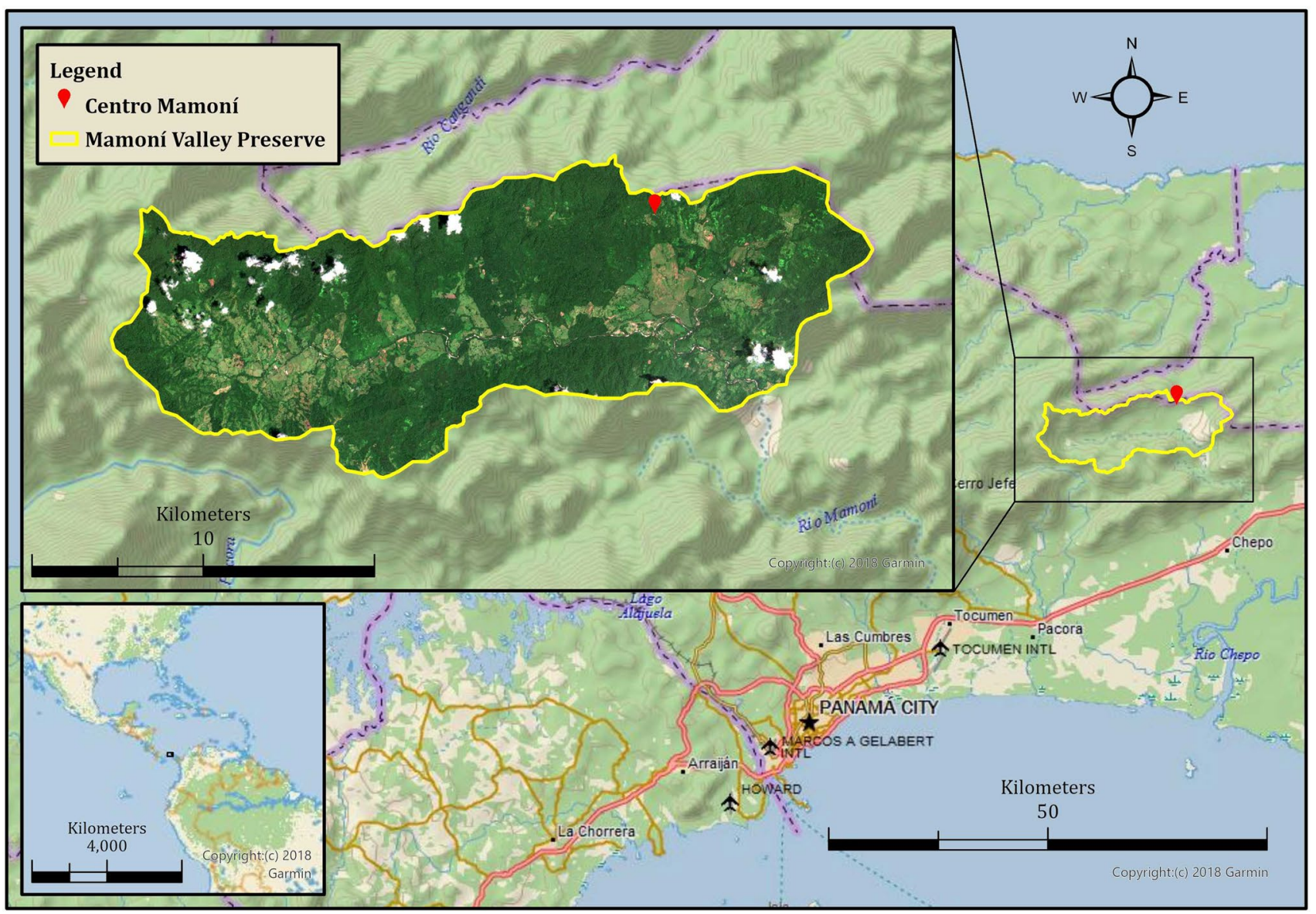

Fig. 6 Located at the narrowest part of the Panamanian Isthmus, the Mamoni Valley Preserve occupies the upper watershed of the Mamoni River. The Centro Mamoni rainforest campus is about 2-h drive from an international airport. Sentinel II imagery from 2020 shows the mosaic of forest and pasture in this rainforest frontier. Map by University of Redlands student Sean Sampson
Through their interactions with local guides and support staff, school kids and their families, indigenous leaders, and indigenous forest guards, students learn about the history of deforestation in the valley. Hikes and field activities take them through a mosaic of pasture, secondary forests, and stands of old-growth forest left by a history of small-scale agriculture and cattle ranching. Starting in the 1960s, smallscale farmers and cattle ranchers began clearing forest in the valley. A rough road entered in the 1980s and deforestation pressures began to leak out of the Mamoní Valley as settlers and the hired hands of absentee landlords crossed the continental divide into indigenous Guna territory to clear fresh lands for food crops and pastures.

In a well-known example of indigenous resistance, the Guna people demarcated their lands and spent many years firmly evicting settlers from homesteads in Guna territory and turning back settlers at their border with the
Mamoní Valley. In the last several decades, subsistence agriculture and small-scale cattle ranching became less economically viable, and some families began to abandon the valley. This created the threat that large-scale cattle ranchers would consolidate smaller properties and convert much more of the valley to pasture. In 2000, in coordination with the Guna people who were looking for allies to stabilize their frontier, Nathan Gray, a social entrepreneur and sustainable development activist, established a Mamoní Valley campus of Earth Train, an environmental youth leadership training organization he had founded in 1990. Earth Train recruited allies to buy strategic parcels of forest and pasture to prevent the consolidation of small and medium-sized properties into large-scale cattle operations. These actors eventually established the Mamoní Valley Preserve, a 501(c)(3) nonprofit organization using the tools of land ownership, conservation easements, and 
landowner pledges to conserve the extent and quality of the valley's forests and waters, to strengthen biodiversity, to improve the health of the forest's inhabitants, and to promote a sustainable local economy. Currently, the reserve has the explicit support of the landowners in possession of about half of the valley. The goal, however, is to extend forest conservation and sustainable development to the entire upper Mamoní River watershed.

Under Nathan Gray's leadership, Earth Train has evolved into Geoversity, a Panama-based ecosystem of organizations, of which the Mamoní Valley Preserve forms a part (Geoversity 2020). The original installations of Earth Train have evolved into Centro Mamoní, an off-grid jungle lodge at the edge of a vast wilderness preserve with cool showers, microwave (or broadband) internet, a natural swimming pool, solar, and micro-hydro energy, where students sleep in individual tents on covered, raised wooden platforms. Structures here have no walls to separate course participants from the rainforest. Students experiencing the rainforest from this installation may see or hear sloths, multiple species of hummingbirds, tinamous, and even relatives of the same keel-billed toucans and howler monkeys that made a racket during Jane Goodall's plenary session to the AESS in 2009.

\section{GIS integrates environmental experience}

Students experience these environments and social settings as they use GIS to support the Mamoní Valley Preserve's goals of conserving biodiversity, promoting local culture, and supporting a sustainable local economy. They work with the course instructors on parallel and overlapping GIS projects, using recent releases of ArcGIS Pro for all GIS analysis, data management, and visualization (Klooster et al. 2019a). "Where" questions guide these projects. Where are trails and stream courses and the boundaries between tributary catchments? Where are pastures and different types of forest? Where are younger, older, and critical types of forest? Considering the amount of carbon in each landcover type, how much carbon is in each subwatershed and where is it located? Considering the landcover and terrain within each tributary watershed, where are the places most vulnerable to erosion?

Activities to answer these kinds of questions included using Garmin 64 handheld units to gather GPS data to map trails and identify key areas for wildlife observation. We also gathered original landcover data using unmanned aerial vehicles (UAV, aka drones). Drones over the lifetime of the project included DJI Phantom 3, 4, and 4v2, 3DR Solo, and Parrot Disco-Pro AG with a Parrot Sequoia Multispectral camera. For flight planning, we used Pix4D Capture, Maps
Made Easy, and MapPilot. We used the drones to produce natural color images of landcover. ${ }^{3}$ Pix 4D Mapper was used to process the drone imagery into an orthophotomosaic. The resulting layer was imported into our GIS and allowed us to map pastures, forests, and riparian buffers. Combined with a SRTM (Shuttle Radar Topography Mission) digital elevation model, this landcover data allowed us to identify microwatersheds most vulnerable to erosion and siltation and to make riparian buffer restoration planning maps.

Students also measured carbon content in different types of forests and use that data to produce carbon content maps linked to stages of forest succession. These projects help reserve managers visualize the locations of trails, streams, watershed management units, pastures and forest types, areas of similar carbon content, and the parts of watersheds that are most vulnerable to erosion. Over time, the idea is to build a thorough geographic database of increasing value for reserve management. Meanwhile, GIS projects become vehicles for undergraduate students to engage in Experiential Environmental Education.

All class data have been integrated and maintained in an Esri Enterprise Geodatabase and made available to stakeholders through a series of web layers and maps, as well as a variety of export formats such as shapefiles and $\mathrm{kml}$. We have also produced ArcGIS Online and ArcGIS StoryMaps for web-based content delivery and presentations.

\section{Trail mapping}

Some of the most accessible rainforest experiences come from hiking trails and observing the plants, animals, and landscapes along the way. Students used GIS to create trail maps and accompanying text which could communicate trail features for subsequent visitors. This activity required students to hike trails, record observations, and consider what elements of forest dynamics and rainforest ecology to include in the maps and trail descriptions. As a GIS exercise, they also learned to incorporate GPS tracks into a GIS, and use GIS tools to calculate parameters such as length and elevation gain. The activity required them to analyze, catalogue, compare, and communicate the experience of hiking through the rainforest. Maps and descriptions were compiled into a laminated booklet to be shared with subsequent visitors to the reserve (Fig. $7 \mathrm{a}$ and b).

\footnotetext{
${ }^{3}$ We have not yet made use of original multispectral or lidar data during classes taught in the field. In a semester-long, remotely taught version of the class during the spring of 2021, however, we were able to leverage our previous work in the Mamoní Valley to task students to do landcover analysis using lidar data from the Global Ecosystem Dynamics Investigation (GEDI) mission and multispectral imagery from the European Space Agency Sentinel 2 mission. These data allow broader-scale mapping projects and will enrich future fieldbased classes.
} 
Fig. 7 a and $\mathbf{b}$ Trail map and description generated by students participating in the 2019 PanaMapping EEE course

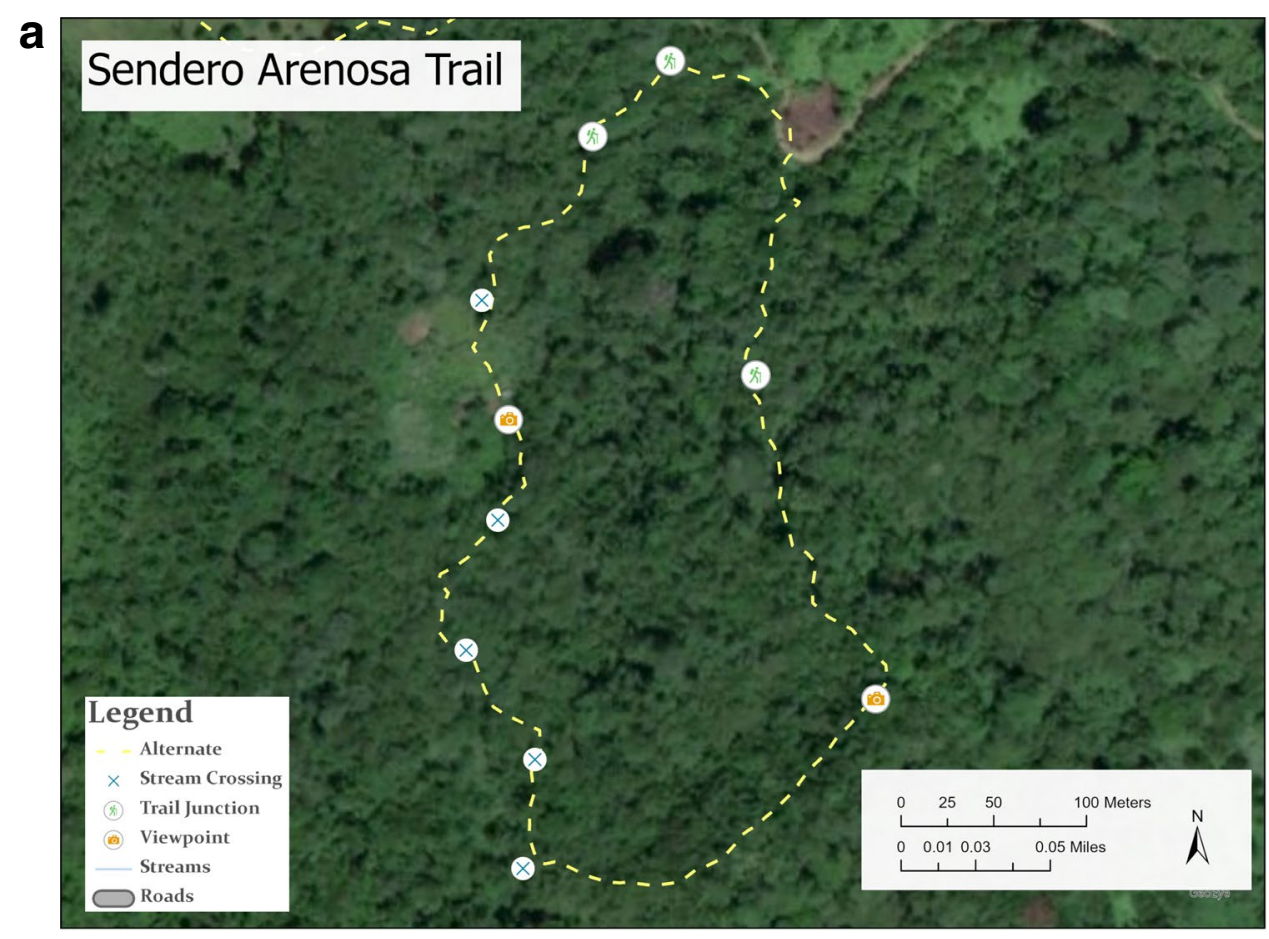

b

\section{Sendero Arenosa Trail}

The Arenosa Trail is a great loop for all hikers ranging from beginners to veterans. The change in elevation is slight, making it an easy climb for hikers of any age and physical condition. The Arenosa is covered by canopy for the majority of the trail, but opens into an agricultural clearing with direct sunlight for a few hundred meters near the end. On this hike there are many stream crossings which will require walking across some small rocks which might mean getting your feet wet. The trailhead is a short distance down the road from Centro Mamoni, and loops back to the road.

\section{Points of Interest:}

You may hear the metallic wing snaps of manakins, or the calls of trogons, motmots, and kingfishers. Small fish swim in the streams and hikers on this trail have sighted mono titi and white faced capuchins monkeys. Farmers in this area tell us that this forest was a pasture in the 1980 's, and throughout the hike you can see various stages of forest succession including mature secondary forests with 'walking palms' ready to lean towards the light made available by a tree fall. A section of the path follows a ridge that rises into the canopy. Along the Arenosa creek, a patch of heliconia with their drooping red flowers looks like it is from another world.
Look for hummingbirds there. The trail passes through an agricultural clearing where farmers grow crops such as culantro, plantain, and root vegetables including cassava (yuca) and taro. Highways for leafcutter ants cross the trail, traversed by workers carrying chunks of leaves back to their colony to feed the fungus that they harvest for food.

\section{Risks/Hazards:}

The Arenosa has several stream crossings and an area of potentia mud which make rubber boots ideal. Short sections of the trail follow water courses, which can be stony and slippery. If especially heavy rains occur, streams could rise and become difficult to cross. Rain also causes the ground to become softer and more slippery. Spiny chunga palms occur along the trail. Don't touch them.

\section{Peak Elevation: $230 \mathrm{~m} \quad$ Distance: $460 \mathrm{~m}$}

Climb Elevation: $30 \mathrm{~m} \quad$ Starting Elevation: $215 \mathrm{~m}$

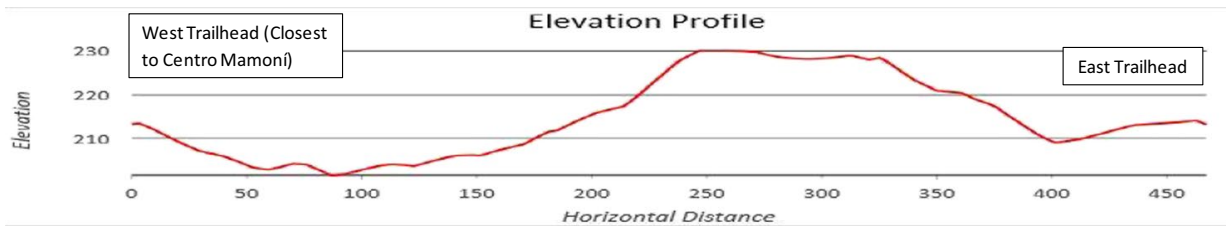

\section{Unmanned aerial vehicles (drones) provide original landcover data}

To truly appreciate the complexity and diversity of the rainforest, you must immerse yourself in it, walking trails and looking up at the trees overhead-and to understand the structure and health of the rainforest, it helps to get above the tree canopy and see it at a much broader scale. Unmanned aerial vehicle (UAV), or "drones," allow students to gain this perspective and evaluate forest types and tree density, assess stand maturity, identify areas of deforestation, monitor forest restoration efforts, and much more. Drone image acquisition is especially useful in Panama, where cloud cover so frequently interferes with standard satellite platforms. An added benefit to gaining experience using drones in GIS instruction is that students have the opportunity to be 


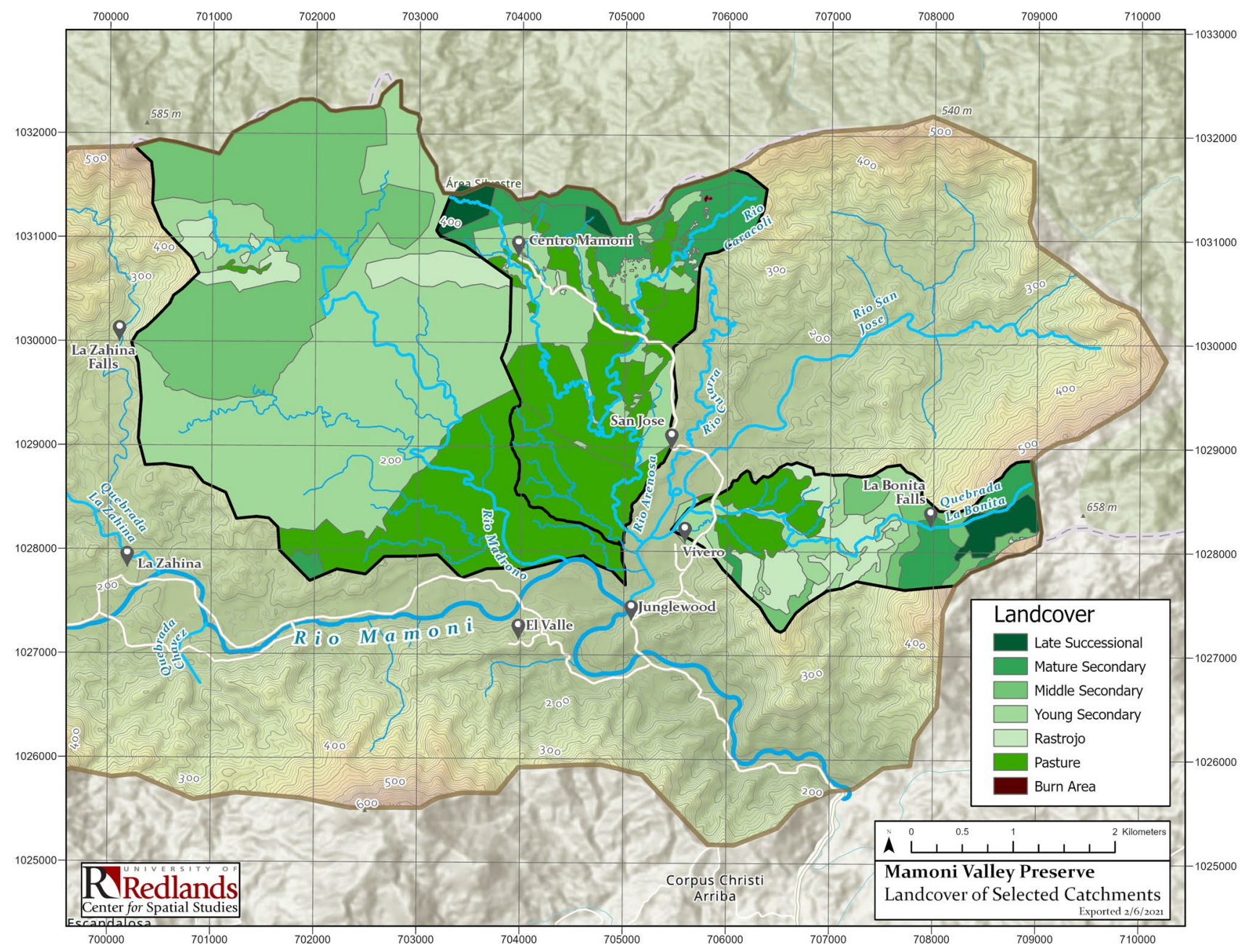

Fig. 8 Landcover map produced by University of Redlands Students

involved in all aspects of image acquisition and photogrammetric processing of the imagery that they ultimately use in their analyses. Acquiring UAV data requires developing a landscape perspective, planning flights, and hiking to launch points. Once acquired, the data provides what Monty called an "avian" perspective on the rainforest which complements the other ways in which they are experiencing rainforest environments and learning about the social dynamics of forest loss and conservation (Cited in Klooster et al. 2019b).

\section{Mapping forest types and carbon density}

Forest mapping provides another avenue to enrich Experiential Environmental Education in the Panama course. The orthomosaics generated by UAV remote sensing provide highly detailed visual information useful for enriching boots-on-the-ground perspectives. However, GIS visualizations and analyses also permit students to develop an analytic interpretation of landcover that identifies areas of generally similar characteristics and helps them develop an understanding of forest ecology and its relationship to social dynamics. Students worked with a professional forester familiar with the area in the process of developing such maps through the interpretation of the high-resolution natural color vegetation images from our drones. They learned to understand and recognize groups of trees generally similar in composition and age (forest stands) and the series of successional phases a forest stand goes through over time as it recovers from a disturbance such as being cleared for agriculture and pasture (chronosequences). Students learned such concepts in theory, and then took to the field to recognize key landcovers on location and on the UAV imagery. They then used GIS to do onscreen digitizing of the drone imagery to delineate landcovers and to produce landcover maps (Fig. 8).

Similarly, carbon mapping encourages students to think about the relationships between forests, the global carbon cycle, and human activities, including their own air travel. 
Fig. 9 University of Redlands student using a clinometer to estimate above-ground carbon content

Forests provide an important environmental service by capturing carbon and holding it out of the atmosphere. Conversely, carbon emissions from deforestation contribute to global greenhouse gas emissions. Mamoní Valley
Preserve managers, therefore, wish to visualize and communicate how much carbon they are managing and where it is located.

Tasked with answering the question "where is the carbon?," students worked from their understanding of the science of forest succession in a temporal, non-spatial sense, then developed basic skills in the science of forest mensuration. A forester taught students key skills in measuring tree diameter, height, stand density, and how to calculate carbon content based on original field measurements. Using these skills, student teams gathered data in sample plots representative of the different landcovers and forest succession types appearing in the landcover map (Fig. 9). This process yielded carbon density figures for each landcover type. These values were then assigned to each of the landcover categories to produce a carbon map. This allows landscape-level calculations of carbon content and landscape maps of carbon densities (Fig. 10).

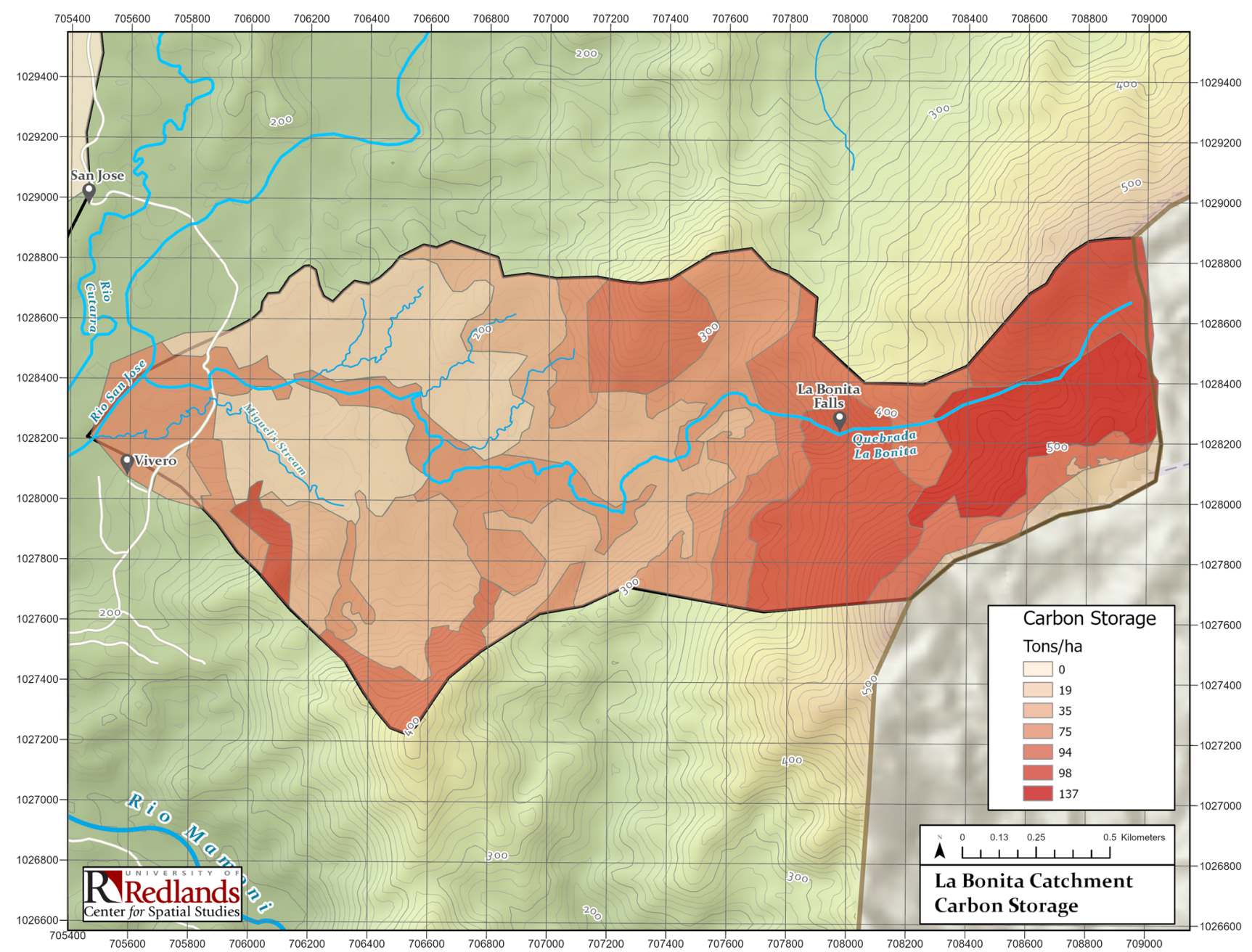

Fig. 10 Carbon map produced by University of Redlands students 
Fig. 11 University of Redlands student experiencing a high carbon content forest (Klooster et al. 2019a)

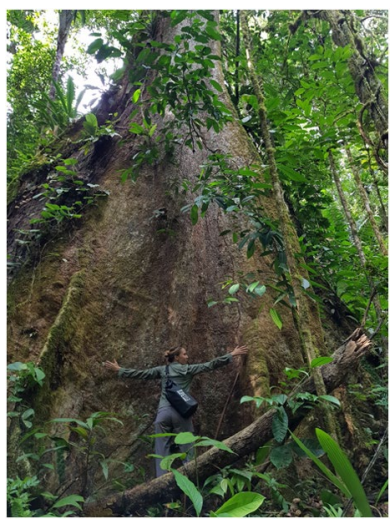

The process of carbon mapping reinforces an environmental education that includes concepts of carbon sequestration and the role of forests in global climate change mitigation strategy. But perhaps more importantly, it immerses students in the scientific process of data gathering as they learn to estimate the heights of trees, measure their diameters, count individuals in a given area, and defensibly extrapolate their findings to a landcover type and then to a landcover map. Students also learn to recognize the characteristics of young stands of trees compared to old ones so they begin to perceive the role of forest succession in creating a landscape, and as they create and interpret land cover maps, they learn about the social process of deforestation, conservation, and forest recovery. Some of our most intimate rainforest immersion experiences came during the hands-on process of gathering the plot-level data needed to develop carbon maps for the Mamoní Valley Preserve (Figs. 11 and 12).

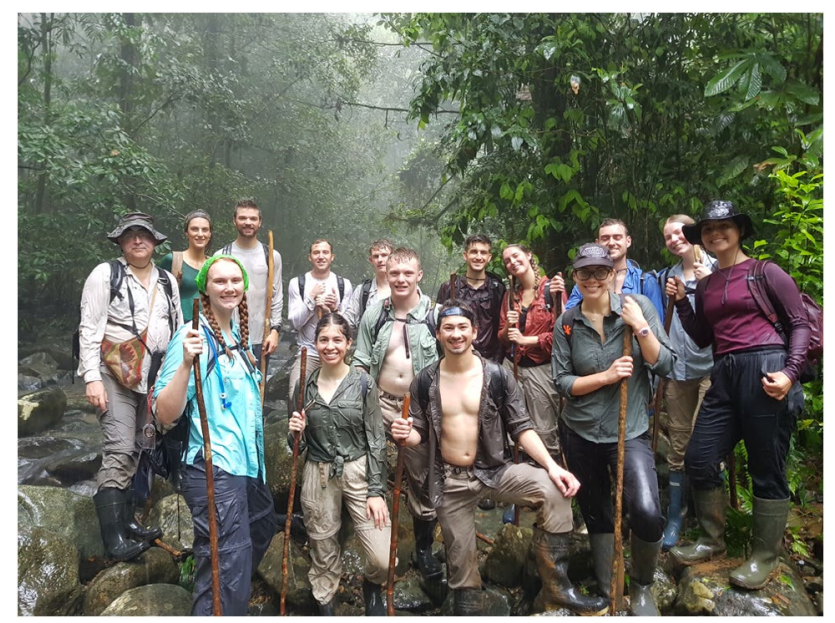

Fig. 12 Students mapped original data collected in streambeds and related their streambed observations to their GIS visualizations of the stream's watershed

\section{Watershed analysis}

The Mamoní Valley Preserve encompasses the watershed of the upper Mamoní River, which is itself composed of multiple catchment tributaries draining into the main course of the river. GIS allowed students to develop a thorough, experience-based understanding of the watershed concept as they analyzed the comparative erosion vulnerability of catchments selected by reserve managers. This project answered multiple "where" questions essential for management:

- Where are the catchment boundaries?

- Where is the stream and significant tributaries?

- Where are steep slopes and flat areas?

- Where are forests and pastures in this watershed?

- Where do streams have riparian buffers and where are these absent?

- Where are slopes and streams most vulnerable to erosion and degradation?

Answering these questions generated a series of enriching experiences, environmental immersions, and an education in basic watershed concepts. Students used GIS to analyze a digital elevation model (DEM) to identify initial watershed boundaries. Where topography was insufficiently abrupt for this method to work, they hiked catchment divides using GPS to trace the high points separating catchments. Existing data on stream courses contained numerous errors, and so students also hiked the creek beds with GPS to create more accurate data on stream locations. As they hiked, they observed channel shapes and the size of rocks and gravel as indicators of erosion and stream energy. They also observed tree cover on the streambanks, and later used these observations to map areas where riparian buffers were absent, partially present, or provided full coverage (Fig. 11). GIS gave students tools to create stream profiles showing steepness along the valley and maps showing slope gradients along the valley's sides. GIS also allowed them to overlay landcover with slope maps to identify potentially vulnerable areas where erosion-prone landcovers occur on erosion-prone slopes (Fig. 12).

The previously created UAV landcover data and resulting map shows the locations and extent of pastures and different forest types, but to more accurately map riparian barriers, students did a separate visual analysis of the UAV orthomosaic, with field verification combined with GPS mapping of stream courses. Finally, student researchers used GIS to overlay these maps to locate areas of concern, such as steep slopes under pasture adjacent to streams unprotected by a riparian buffer.

Meanwhile, as they use GIS to analyze watersheds, students think about the connections in a landscape. They visualize links between landcover, slope, and erosion. They 


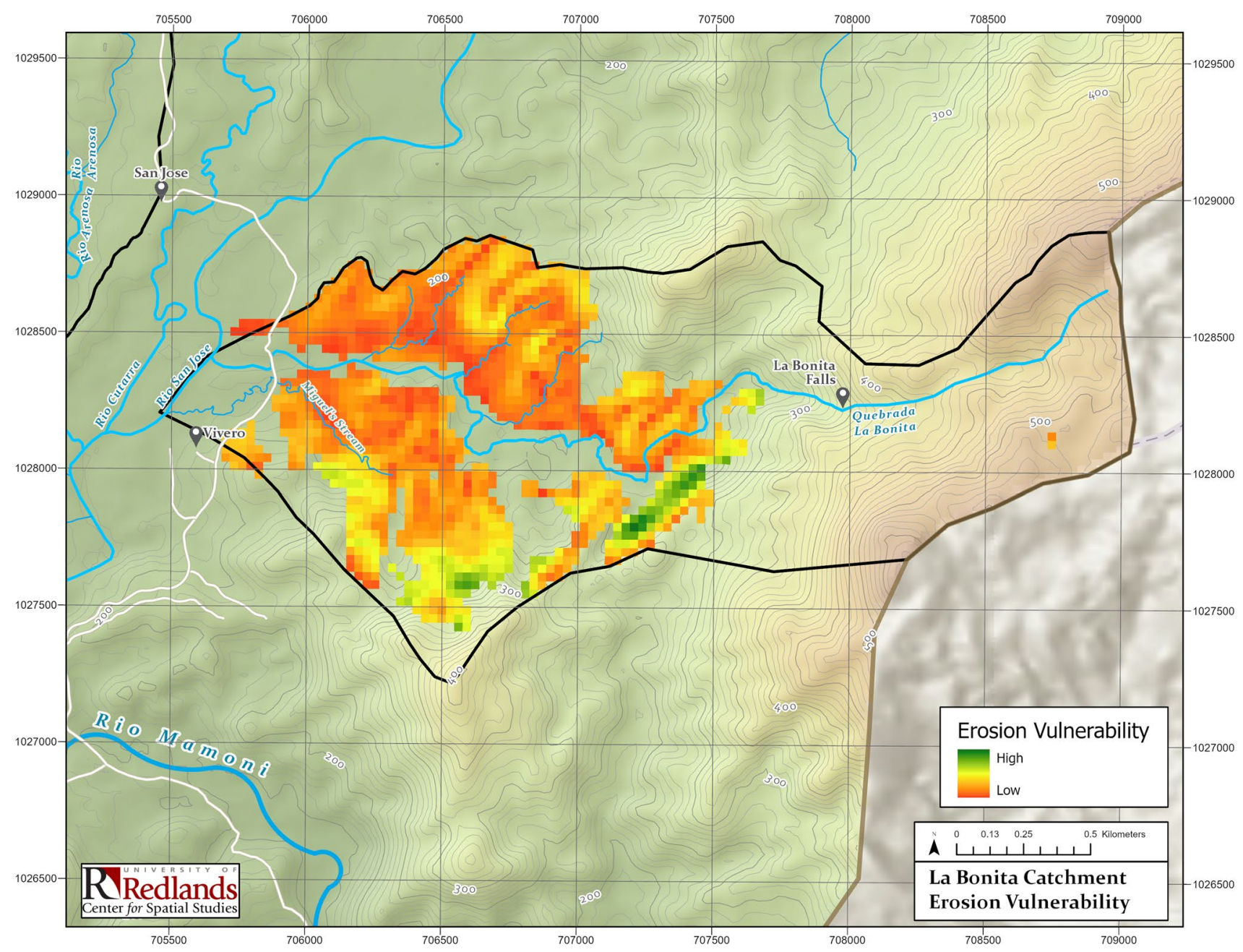

Fig. 13 Students used GIS to overlay landcover data from UAV with slope to locate areas comparatively vulnerable to erosion

consider the role of riparian barriers in buffering streams from the runoff from cattle pastures. Using GIS tools, they can better visualize, interpret, and communicate the watershed: Here is an area where a steep slope has been deforested! Here is where lack of riparian buffer makes the stream vulnerable to erosion and nutrient enrichment from that pasture (Figs. 13 and 14)! In this way, GIS helped them integrate their environmental experiences and their environmental education into opportunities for constructive learning while producing map products useful for reserve management.

\section{Documenting deforestation with the Majé Emberá}

While the bulk of the EEE field course is based in the Mamoní Valley Preserve, the course also includes site visits designed to provide students with learning experiences that shed greater light on the relationship between indigenous land rights, exclusionary development policy, and conservation strategy. Some students built on this experience to write capstone theses and present findings at conferences (Bohman 2018).

After course participants traveled by boat over lake Bayano and up the Majé river to a traditional Emberá village, the village leader Cacique Lorenzo Mecha shared his people's experience with being displaced by development projects, struggling unsuccessfully to secure formal land rights, and being marginalized from participation in conserving their remaining territory. On a map provided by the indigenous rights and advocacy organization Forests of the World, he showed the class where his people were flooded out in 1976 when the Lago Bayano Hydrolectric Dam was created to provide power to Panama City (Figs. 15 and 16). "We had to give up our lands so the rest of the country could have electricity, but we don't have electricity, or water, or even rights to the remnant of our territory that we live on," he told us (Klooster et al. 2019a). He pointed out discrepancies between the GPS track he and his brother produced by 


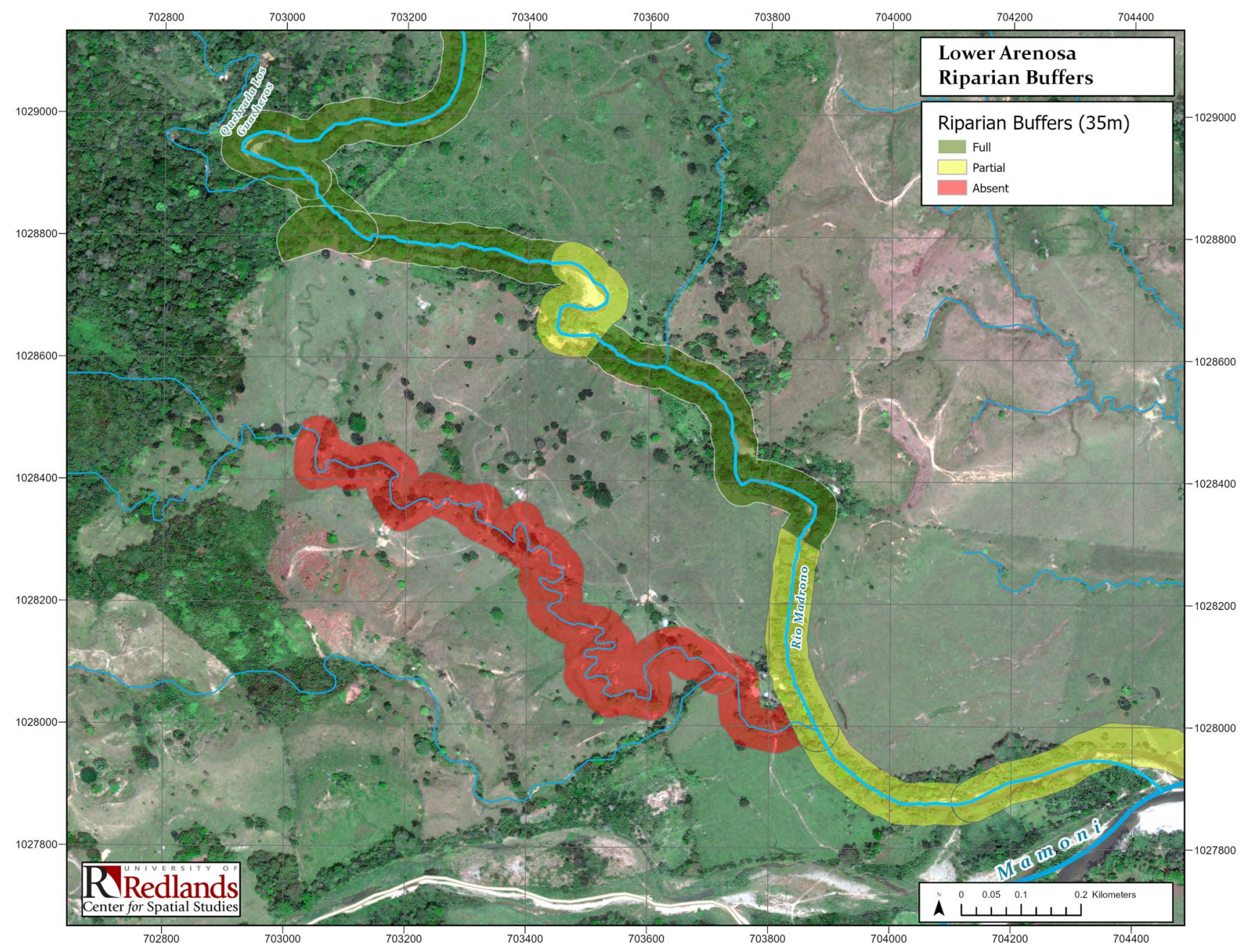

Fig. 14 Students created visualizations of watercourses lacking tree cover

hiking along the ridges that define the Majé River conservation area. Their on-the-ground knowledge is much more accurate than the official designation of this area.

Fig. 15 Leaders of the Majé Emberá orient University of Redlands students and faculty to the challenges they face protecting their territory from deforestation. Based on their conversation, students programmed a UAV flight to document recent deforestation (Klooster et al. Geoversity 2019a)

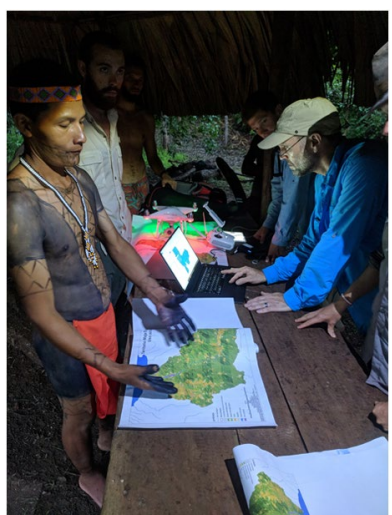

Fig. 16 GIS activities and UAV provide opportunities for University of Redlands students to interact with the Majé Emberá 
Students learned that the Pan-American Highway penetrated the region in 1979, and with it came loggers and colonists who cleared forests for pasture. Cacique Lorenzo showed us areas on this map where his people used to collect medicinal plants to support healthy pregnancies and to cure the sick. Many of those areas are deforested now. Later, on walks near the village, students saw, touched, and smelled some of this ethnobotanical pharmacy in semi-wild areas where community members transplanted those plants from forests being cleared elsewhere in the community's territory.

The core of the problem, Cacique Lorenzo told the class, is that his people's remaining lands have been declared a conservation area, and this means they cannot officially own them, protect them, or manage them. But conservation authorities cannot or would not provide adequate stewardship of this area; they fail to protect the watershed's forests from loggers, colonists, and ranchers. Settlers have cleared large areas of pasture near the village. A fire set to clear forests for pasture spread into the valley of the creek that the Maje Emberá use for drinking water, destroying their village aqueduct. Students learned that the Emberá have been struggling for land titles here since 1960, but so far, the "protected" designation of their lands prohibits titling.

EEE in this case included a contribution to the Majé Emberá Drua's struggle to protect their forests. Cacique Lorenzo pointed out an area he knows is being deforested and asked students to collect land cover data there using the class' UAV. The Majé Emberá will use the UAV imagery to support their ongoing campaign to defend their territory from encroachment and to help them lobby the Panamanian government for land rights to defend what is left of their ancestral territory. GIS, and original data from drones, allow students to participate in environmental education experiences in which they can learn these histories and contribute to the Emberás' struggle to conserve their forest.

EEE helped students see that the Majé Emberá perceive conservation differently than we do. They saw that the Majé Emberá have a direct and intimate relationship with conservation, that they jealously conserve a micro-watershed for their own drinking water, and that they hunt, fish, farm, and gather medicinal herbs from a large area. They depend directly and intimately on functioning forest ecosystems, but they are victims of both development and misguided conservation strategy. EEE makes the potential synergy between indigenous rights and conservation strategy quite obvious. Students learn that the Emberá are essential actors in achieving conservation who use forests without converting them to pasture, report deforestation to authorities, and are engaged in a legal struggle to establish land rights that would enable them to be better stewards of conservation. This experience helped students understand some of the challenges of integrating mapping technologies with on-theground knowledge and perspectives of indigenous people.
They saw how geospatial environmental knowledge (GEK) complements, but does not replace or adequately represent, traditional environmental knowledge (TEK) (following Kimmerer 2012).

\section{GIS for Experiential Environmental Education}

Student projects develop and integrate data on land cover, watersheds, land ownership, carbon storage, and trails into an enterprise geographic information system (GIS) of utility for the Mamoní Valley Preserve. GIS activities contribute to conserving the rainforest, but they also advance students' environmental education.

Meanwhile, GIS becomes the warp bringing together other elements into a fabric of Experiential Environmental Education. GPS mapping gets students into the forest walking along trails, tracing ridgelines, and wading in creeks. GIS mapping projects permit students to visualize and analyze the connections between overlapping environmental systems, such as forest cover, watersheds, and topography. GIS also facilitates the visualization and analysis of human systems interacting with the environment, such as settlements, roads, trails, pastures, and property boundaries. In GIS, students extend data from direct, hands-on forest measurement to a landscape mapped into discrete forest types with varying carbon content. While doing GIS projects, students generate their own understandings of the social and ecological dimensions of rainforest destruction and conservation.

In Monty Hempel's words, "Mapping a watershed or rainforest ecosystem is like drawing a floorplan for one's home. It seems rather prosaic, when in fact it is how we visualize complex information needed to develop a systems understanding of our environment. The PanaMapping project, with its reliance on advanced geospatial and drone technology, makes it possible to integrate the human perspective of ground-level fieldwork with the avian perspective of interlocking ecosystems. Together they help transform our understanding of the system of systems that is Nature and the interdependence that characterizes all life on Earth" (Cited by Nathan Gray in Klooster et al. 2019b).

The course combines the integrative benefits of GIS for environmental education (Hwang 2013) with the value of highly immersive Experiential Environmental Education (Felege et al. 2019). Just as Monty envisioned GIS, therefore, participating in "GIS in the Jungle" encourages students to develop an appreciation of interconnected environmental and human systems. By mapping, visualizing, and analyzing these system components together, students develop an integrative, analytic understanding of a Panamanian rainforest frontier. Also, just as Monty envisioned 
immersive learning in the field, doing "GIS in the Jungle" means students also develop an appreciation for the beauty of natural environments and for the challenges we face in conserving them.

Acknowledgements Unless otherwise attributed, photographs are from participants in PanaMapping courses. Panamapping courses would have been impossible without the irreplaceable contributions from the student researchers whose work is presented here: Michael Adami, Zachary Booker, Harrison Cannon, Serena Dudas, Taiga Gamell, Kyle Garrity, Javier Gasga, Nicholas Graff, Enrique Huerta, Chris Merritt, Sarah O'Connor, Torrey Rotellini, Zachariah Smith, Meera Srinath, Will Tyrell, Graham Young, Akio Anderson, Luis Salgado, Joe Imburguia, Kaitlyn Dreissnack, Jessica Pierce, Jordan Hooey, Veronica Creed, Abigail Bohman, Ian Matsumoto, Sumner Macpherson, Taryn Fowlkes, Ava Gotthard, Sarah Graham, Trevor Broulette, Tim Broz, Ian Davidson, Brianna Hernandez, Carter Kerwin, Ava Klein, Riley Lathrop, Claire Napier, Caillie Roach, Tony Sidor, Jake Walters, and Sam Wyner. Our safety, comfort, and success in the field depended on the work of Mark Knetsch, Ana Gili, Nico Armstrong, Ezequiel Coniglio, and Gabriel Salazar. Kike Arias, Matthew Brewer, Venicio Wilson, and Tim Krantz provided crucial instructional enhancements. Lazaro Mecha, Narciso Mecha, and Clemente Mecha hosted student researchers in their village. Steve Moore and the University of Redlands Center for Spatial Studies provided crucial equipment and GIS support. Thanks also to Myrna James, Publisher/Managing Editor, Apogeo Spatial.

\section{References}

Atalan-Helicke N (2014) Learning and promoting urban sustainability: environmental service learning in an undergraduate environmental studies curriculum. J Environ Stud Sci 4:294-300. https://doi.org/ 10.1007/s13412-014-0194-8

Bohman A (2018) Indigenous knowledge and rainforest conservation. Paper presented at the society for conservation GIS $21^{\text {st }}$ annual conference. Asilomar Conference Center, Monterey CA, July 17, 2018

Brenner JC, Hamilton JG, Drake T et al (2013) Building local environmental knowledge in undergraduates with experiential wilderness skills and awareness training: the case of environmental sentinels. J Environ Stud Sci 3:404-415. https://doi.org/10.1007/ s13412-013-0145-9
Felege C, Romsdahl R, Hunter J et al (2019) Immersive field experiences lead to higher-level learning and translational impacts on students. J Environ Stud Sci 9:286-296. https://doi.org/10.1007/ s13412-019-00555-y

Geoversity (2020) Geoversity. Geoversity.org. Accessed 21 July 2021

Hempel M (2012) Mother nature, CEO: earth train expedition 2012. Blue planet united and earth train. https://youtu.be/ouftNVYlhkE. Accessed 21 July 2021

Hwang S (2013) Placing GIS in sustainability education. J Geogr High Educ 37(2):276-291. https://doi.org/10.1080/03098265.2013. 769090

Jakab I, Ševčík M, Grežo H (2017) Model of higher GIS education. The Electronic Journal of e-Learning 15(3):220-234

Jose S, Patrick PG, Moseley C (2017) Experiential learning theory: the importance of outdoor classrooms in environmental education. Int J Sci Educ, Part B 7(3):269-284. https://doi.org/10.1080/21548 455.2016.1272144

Kimmerer RW (2012) Searching for synergy: integrating traditional and scientific ecological knowledge in environmental science education. J Environ Stud Sci 2:317-323. https://doi.org/10.1007/ s13412-012-0091-y

Klooster D, Smith D, Strout N, Experience Mamoní, Fundación Geoversity (2019a) PanaMapping: GIS for conservation science. In: Wright D, Harder C (eds) GIS for science: Applying mapping and spatial analytics, vol 1. Esri Press, Redlands, pp 200-213

Klooster D, Smith D, Strout N, University of Redlands; and Fundación Geoversity (2019b) PanaMapping: GIS for conservation science, The Mamoní Valley Preserve. Apogeo Spatial, 2. http:// apogeospatial.com/panamapping-gis-for-conservation-scien ce/. Accessed 21 July 2021

Lo CP, Affolter JM, Reeves TC (2002) Building environmental literacy through participation in GIS and multimedia assisted field research. J Geogr (Houston) 101(1):10-19. https://doi.org/10. 1080/00221340208978462

Moseley C, Summerford H, Paschke MP, C. \& Utley J. (2020) Road to collaboration: experiential learning theory as a framework for environmental education program development. Appl Environ Educ Commun 19(3):238-258. https://doi.org/10.1080/15330 15X.2019.1582375

Sinton DS (2009) Roles for GIS within higher education. J Geogr High Educ 33(sup1):S7-S16. https://doi.org/10.1080/0309826090 3034046

Publisher's note Springer Nature remains neutral with regard to jurisdictional claims in published maps and institutional affiliations. 